\title{
PEMBUATAN MESIN PENGELUPAS KEDELAI UNTUK MENINGKATKAN PRODUKSI
}

\author{
Muhammad Khumaedi, Sudarman, Dwi Widjanarko, Imam Sukoco \\ Jurusan Teknik Mesin, Fakultas Teknik, Universitas Negeri Semarang \\ Email: Muhammad_khumaedi@mail.unnes.ac.id
}

\begin{abstract}
This service activity program is carried out with the aim to help the problems faced by the small business of tempeh making "Jumari" which experience problems in production where the peeling of its soybeans is still done traditionally by stepping on soybeans, so that the processing process takes long, the tempeh quality is not clean and the tempeh production is not optimal. The solution to help the problems faced by making soybean peeling machines, providing training on machine use, accompanying them to be able to increase tempeh production and evaluate its activities. Based on the evaluation results of this empowerment service, we have obtained a soybean peeling machine and there is an increase in production, where the time to peel soybeans is faster than before, the quality of the tempeh results is cleaner, and there is an increase ofthe business owner's income.
\end{abstract}

Keywords : empowerment; small business; tempeh; improve; product

\begin{abstract}
Abstrak. Program kegiatan pengabdian ini dilaksanakan dengan tujuan untuk membantu permasalahan yang dihadapi oleh usaha kecil pembuatan tempe "Jumari" yang mengalami permasalahan dalam produksi dimana pengelupasan kedelainya masih dilakukan secara tradisional dengan menginjak injak kedelai, sehingga proses pengerjaan lama, kualitas tempenya tidak bersih dan hasil produksi tempenya tidak maksimal. Solusi untuk membantu permasalahan yang dihadapi adalah dengan membuatkan mesin pengelupas kedelai, memberikan pelatihan penggunaan mesin, mendampingi sampai dapat meningkatkan produksi tempe dan melakukan evaluasi kegiatan. Berdasarkan hasil evaluasi dari pengabdian yang berupa pemberdayaan ini adalah telah didapatkan mesin pengelupas kedelai dan ada peningkatan produksi, dimana waktu untuk mengelupas kedelai lebih cepat dari sebelumnya, kualitas hasil tempe lebih bersih, dan adanya peningkatan laba bersih.
\end{abstract}

Kata kunci: pemberdayaan; usaha kecil; tempe; meningkatkan; produksi

\section{PENDAHULUAN}

Tempe adalah makanan tradisional yang sangat disukai oleh masyarakat, biasanya digunakan sebagai bahan 'lauk makan dan cemilan'. Rasanya yang enak dan pengolahan yang mudah menyebabkan tempe sering menjadi menu 'makanan utama' pada tiap keluarga.

Tempe kedelai adalah merupakanan jenis pangan yang pembuatannya dilakukan secara fermentasi dari kedelai oleh kepang yang berbentuk padat dan berwarna putih sedikit keabuan yang baunya khas. Pada perkembangannya dengan kemajuan ilmu 
pengetahuan dan teknologi, sekarang tempe tidak hanya dibuat dari kedelai. Sekarang tempe banyak juga yang dibuat dari bahan lain sesuai potensi yang ada pada daerah tersebut. Meskipun sudah banyak produk tempe dari berbagai bahan baku, namun tempe dari bahan kedelai inilah yang paling banyak dikenal dan disukai masyarakat di Indonesia.

Mengingat pentingnya tempe untuk memenuhi gizi pangan bagi masyarakat, maka tim pelaksana akan melakukan pemberdayaan pada usaha kecil pembuatan tempe "Jumari" yang dimiliki Bapak Jumari yang beralamat di Jalan Dewi Sartika RT 07 RW 03 Kelurahan Sukorejo Kecamatan Gunungpati Kota Semarang yang dalam pembuatan tempenya masih dilakukan secara tradisional dengan cara dinjak injak. Usaha pembuatan tempe "Jumari" setiap harinya menghabiskan kedelai sebanyak $125 \mathrm{~kg}$. Dari bahan kedelai sebanyak itu dapat menghasilkan tempe sekitar 900 potong yang dibungkus plastik. Pembuatan tempe memerlukan waktu yang lama, kurang lebih tiga hari. Atas dasar itu usaha pembuatan tempe "Jumari" melakukan produksinya tiga lapis yang berurutan. Dengan cara demikian tiap hari tempe yang dibuat dapat dijual.

Setiap harinya tempe dari hasil usaha kecil "Jumari" selalu habis terjual. Dengan demikian tempe yang dijual tiap hari merupakan tempe baru yang 'segar' yang dibuat tiga hari sebelumnya. Berdasarkan wawancara dengan pemilik usaha "Jumari" diketahui bahwa dari usahanya tersebut setiap harinya mendapat laba bersih sekitar Rp.350.000 sampai Rp.400.000.

Seperti dijelaskan di atas, bahwa untuk menghasilkan tempe yang siap jual dilakukan melalui beberapa proses pengerjaan. Untuk itu agar mendapatkan gambaran tentang alur proses dari mulai pertama proses pembersihan kedelai sampai pada tahap penjualan tempe pada usaha kecil pembuatan tempe "Jumari" beserta permasalah yang dihadapi dapat diuraikan sebagai berikut.

Pekerjaan pertama pada usaha pembuatan tempe "Jumari" adalah melakukan pembersihan kedelai. Pembersihan kedelai dilakukan pada dini hari sekitar jam 03.00. Pembersihan ini dimaksudkan untuk membersihkan kotoran kotoran yang ada di kedelai, akan sangat baik apabila pembersihan dilakukan pada air yang mengalir, dengan pembersihan ini kotoran yang tercampur dan melekat akan mengapung sehingga akan lebih mudah dibersihkan.

Setelah itu kedelai direbus selama kurang lebih 30 menit. Caranya kedelai dimasukan ke dalam panci atau dandang yang dipanaskan. Perebusan dilakukan sampai kedelai setengah matang, sehingga kulit ari kedelai hampir terkelupas.

Selesai direbus, sekitar jam 04.00 kedelai dibiarkan beberapa saat, airnya dibuang lalu dalam keadaan masih basah dilakukan pengelupasan kulit kedelai. Pengelupasan kulit kedelai masih dilakukan secara tradisional dengan memasukan kedelai di dalam ember lalu dinjak injak (lihat Gambar 1). Pengelupasan kulit kedelai dengan cara dinjak injak akan menyebabkan pengelupasan lambat, memerlukan waktu lama, kedelai pecah dan kurang berkualitas karena bercampur kotoran dan juga bisa kemasukan batu kecil (Nasirwan, Safril dan Adril 2007: 1).

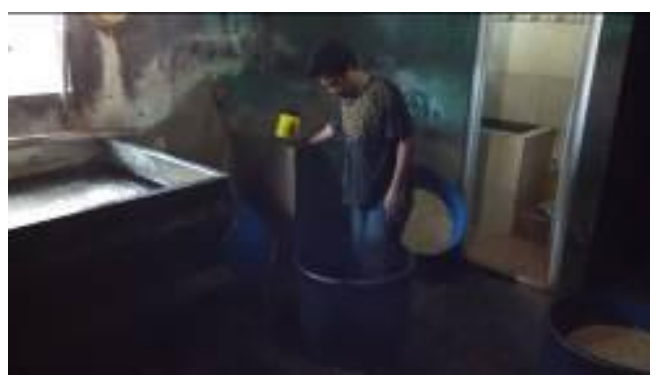

\section{Gambar 1. Pengelupasan kedelai dengan cara menginjak injak di dalam ember}

Setelah itu kedelai direndam dengan air pada suhu kamar dibiarkan di dalam panci atau dandang selama sehari semalam (22-24 jam). Maksud dari perendaman ini adalah untuk terbentuknya bakteri asam laktat yang dapat mencegah pembusukan selama fermentasi dan agar kedelai menjadi lunak.

Pekerjaan berikutnya adalah perebusan kembali dengan merendam di dalam air selama kurang lebih satu jam. Maksud dari perebusan ini adalah agar kedelai menjadi matang dan juga 
untuk membunuh bakteri yang tumbuh selama dilakukan perendaman.

Setelah direbus air dibuang dan kedelai dicuci kembali, lalu airnya ditiriskan. Biarkan kedelai dingin dan kering sampai airnya habis. Setelah itu kedelai diinokulasi dengan diberi inokulum bubuk (ragi/laru tempe) dengan perbandingan untuk $1 \mathrm{~kg}$ kedelai dicampur dengan 1 gram ragi/laru tempe. Bahan kedelai dan ragi/laru tempe kemudian diaduk aduk hingga tercampur merata.

Kedelai yang sudah tercampur dengan ragi/laru tempe kemudian dimasukan dalam bungkus plastik sambil dibentuk menjadi segi empat. Setelah itu tempe yang sudah dibungkus di tata dalam rak dan dilakukan pemeraman/diinkubasikan (dibiarkan) selama 40-48 jam pada suhu kamar dan tidak boleh terkena matahari langsung (lihat Gambar 2).

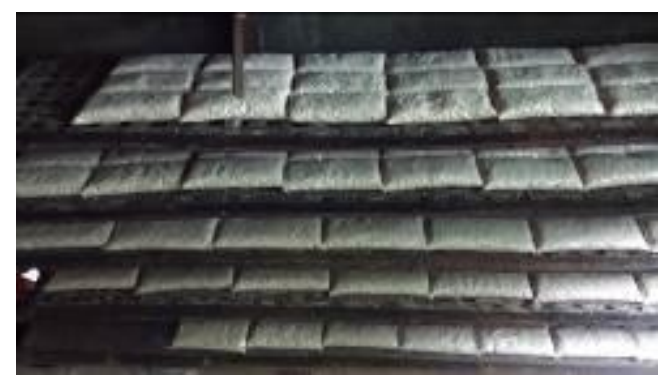

Gambar 2. Pemeraman tempe yang ditata dalam rak

Setelah dilakukan pemeraman satu malam, tempe yang ada di dalam plastik ditusuk tusuk pakai lidi. Tujuan penusukan adalah agar udara segar dapat masuk dalam tempe. Selanjutnya dilakukan pemeraman satu malam lagi, dan esok paginya sekitar jam 05.00 tempe siap untuk dijual. Tempe yang sudah jadi hasil produksi dari usaha pembuatan tempe "Jumari" kemudian diambil oleh penjual tempe keliling dan juga di jual ke warung penjual kebutuhan pokok sehari hari.

Berdasarkan wawancara dengan pemilik usaha pembuatan tempe "Jumari" permasalahan yang ada pada usaha yang dimilikinya adalah aspek produksi. Dimana pengelupasan kulit kedelainya masih dilakukan secara tradisional. Menurut Bapak Jumari akibat pengelupasan kedelai yang masih tradisional dengan cara menginjak injak kedelai menyebabkan tempe yang dihasilkan sering berwarna agak gelap dan sering kemasukan batu kecil serta kotoran, disamping itu juga pengerjaan pengelupasan kedelainya lama.

Keinginan dari Bapak Jumari adalah untuk meningkatkan produksi dengan minta dibuatkan mesin pengelupas kedelai, supaya kualitas tempenya lebih bersih, dan waktu pengelupasannya menjadi lebih cepat, sehingga nantinya produksi tempe yang dihasilkan menjadi lebih banyak dan ini akan meningkatkan laba penjualan tempenya. Juga dari pihak Bapak Jumari meminta supaya penggerak mesin pengelupas kedelai menggunakan penggerak tenaga motor bensin, mengingat keterbatasan daya listrik yang ada di usaha pembuatan tempe "Jumari".

Pengelupasan kulit kedelai dengan menginjak injak masih banyak dilakukan pada usaha kecil pembuatan tempe, seperti hasil penelitian Nasirwan, Safril dan Adril (2007: 2) yang mendapatkan bahwa pengelupasan kulit kedelai dengan cara menginjak injak disamping memerlukan waktu yang lama dan tenaga yang banyak juga menyebabkan biji kedelai pecah dan bercampur kotoran. Hasil penelitian Fauzi (2014: 1) juga menjelaskan bahwa pengelupasan kedelai secara tradisional (dinjak injak) menyebabkan kedelai menjadi pecah karena tekanan pada kedelai tidak beraturan dan memerlukan waktu lama.

Untuk itu solusi yang dilakukan untuk menyelesaikan masalah yang dihadapi usaha pembuatan tempe "Jumari" adalah melakukan pemberdayaan dengan cara membuatkan mesin pengelupas kedelai, memberikan pelatihan penggunaan mesin yang dibuat, dan mendampingi mitra sampai dapat meningkatkan produksi tempenya yang pada akhirnya nantinya akan dapat meningkatkan pendapatannya.

Penelitian yang dilakukan Sayogo dan Suwito (2013: 365) menjelaskan bahwa penggunaan mesin pengelupas kedelai akan dapat membantu di dalam pengelupasan kedelai di dalam pembuatan tempe. Hasil penelitian Fauzi (2014: 6) menyimpulkan bahwa penggunaan mesin pengelupas kulit kedelai 
sangat efektif juga produktif untuk meningkatkan kualitas dan kuantitas hasil tempe. Atas dasar demikian pemberdayaan yang dilakukan dengan membuatkan mesin pengelupas kedelai diharapkan nantinya produksi tempe yang dihasilkan usaha pembuatan tempe "Jumari" kualitas dan kuantitasnya dapat meningkat dengan semakin banyaknya produk yang dapat terjual pada usaha kecil pembuatan tempe "Jumari" maka tentunya labanya juga dapat meningkat. Pembuatan mesin dilakukan dengan membuat terlebih dahulu rancangan gambar susunan lengkap mesin pengelupas kedelai beserta keterangan bagian bagiannya (lihat Gambar 3).

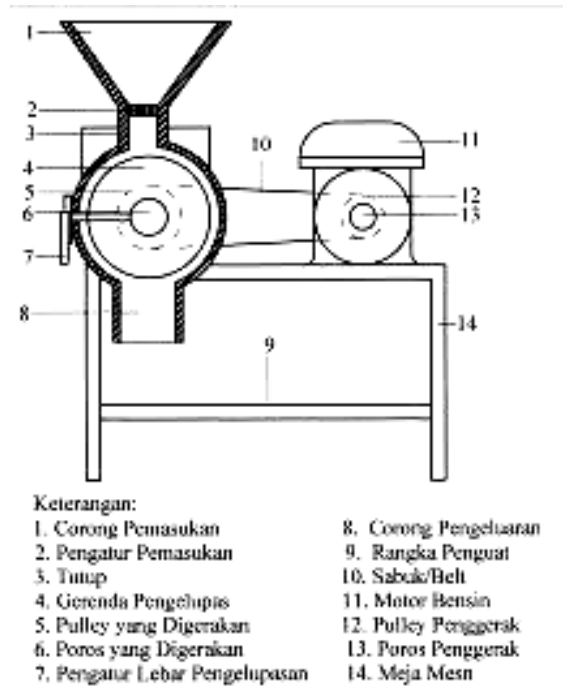

Gambar 3. Rancangan mesin pengelupas kedelai yang akan dibuat

\section{METODE}

Untuk mewujudkan program pemberdayaan yang akan dilaksanakan agar dapat efektif, maka kegiatannya dilaksanakan secara terpadu, yang tahapan tahapannya sebagai berikut: sosialisasi, pembuatan mesin pengelupas kedelai, pelatihan pengoperasionalan mesin, pendampingan mitra dalam kegiatan dan melakukan evaluasi terhadap hasil kegiatan yang dilakukan. Rincian tahapan pelaksanaannya sebagai berikut:

\section{Sosialisasi}

Sosialisasi dilakukan dalam rangka untuk menyamakan persepsi mengenai tujuan kegiatan pengabdian serta manfaat kegiatan yang dilakukan. Sosialisasi juga dalam rangka untuk mendapatkan masukan dari pemilik usaha tempe "Jumari" untuk bagaimana kegiatan sebaiknya dilakukan agar berhasil.

\section{Pembuatan mesin pengelupas kedelai}

Pembuatan mesin pengelupas kedelai adalah untuk membantu menyelesaikan permasalahan yang dihadapi usaha kecil pembuatan tempe "Jumari". Pembuatan mesin melibatkan dosen, teknisi dan dibantu beberapa mahasiswa.

\section{Pelatihan pengoperasionalan mesin}

Pelatihan dilakukan terutama agar karyawan usaha kecil pembuatan tempe "Jumari" dapat mengoperasionalkan mesin pengelupas kedelai yang akan diberikan, sehingga ketika mesin diserahkan para karyawan dapat menggunakannya dengan baik. Disamping itu pelatihan dimaskudkan juga agar para karyawan dapat memperbaiki jika mesin pengelupas kedelai ada masalah.

\section{Pendampingan mitra}

Selama kegiatan berlangsung, tim pengabdi akan mendampingi mitra usaha kecil pembuatan tempe "Jumari" di dalam penggunaan mesin pengelupas kedelai. Pendampingan dilakukan sampai mitra dapat mandiri dan dapat mengelola usahanya dengan baik.

\section{Evaluasi kegiatan}

Evaluasi dilakukan untuk mengetahui apakah setelah kegiatan ini usaha kecil pembuatan tempe "Jumari" dapat menghasilkan kualitas tempe yang lebih bersih, apakah waktu pengelupasan kedelai menjadi lebih cepat, apakah kuantitas tempe yang dijual lebih banyak, dan apakah labanya meningkat. Apabila dari hasil evaluasi pada usaha kecil pembuatan tempe "Jumari" ternyata setelah adanya kegiatan pengabdian yang dilakukan semuanya lebih baik dari sebelumnya maka dapat dikatakan kegiatan ini berhasil. Sedangkan bila sebaliknya atau justru tidak ada perubahan, berarti kegiatan pengabdian tidak berhasil.

\section{HASIL DAN PEMBAHASAN}

Untuk mewujudkan tercapainya tujuan pemberdayaan pada usaha kecil tempe "Jumari" 
tim pengabdi melakukan berbagai kegiatan. Kegiatan kegiatan yang dilakukan dapat dijelaskan sebagai berikut.

Pembuatan mesin pengelupas kedelai, dimulai dengan pemotongan bahan bahan untuk bagian bagian mesin yang dibuat. Pemotongan dilakukan dengan menggunakan mesin gergaji. Adapun bagian bagian yang dipotong adalah poros pengelupas dan rangka rangka untuk meja mesin.

Pekerjaan berikutnya adalah pembentukan bagian bagian yang berbentuk bulat dengan melakukan pembubutan menggunakan mesin bubut. Maksud dari pembubutan ini adalah agar bagian bagian yang berbentuk bulat mencapai ukuran yang sesuai, sehingga nantinya dapat masuk pada lubang lubang pasangannya. Bagian bagian yang mendapat pekerjaan pembubutan adalah poros pengelupas, pulley, rumah poros, handel penguat dan penggerak. Pembuatan bagian bagian pada pekerjaan yang berbentuk datar menggunakan mesin frais. Pengerjaan pengefraisan terutama untuk dudukan motor bensin dan dudukan rumah poros dan kelengkapannya.

Untuk bagian bagian yang tidak dapat dikerjakan dengan mesin dan untuk bagian kecil yang pengerjaannya tidak memerlukan ketelitian yang presisi maka pengerjaannya menggunakan tangan. Bagian bagian yang dikerjakan dengan tangan adalah: pembuatan pengatur pemasukan kedelai, dan penyelesaian untuk penghalusan lubang lubang pasak agar dapat masuk dengan pas.

Untuk menyatukan bagian bagian mesin dari komponen komponen yang perlu disambung atau dijadikan satu dilakukan pengelasan. Bagian bagian mesin yang disatukan atau disambung adalah seperti meja mesin, landasan mesin, penutup pengelupas dan corong pengeluaran kedelai.

Apabila semua bagian bagian mesin telah dipasang. Berarti pekerjaan pembuatan mesin pengelupas kedelai telah selesai dan siap untuk digunakan untuk mengelupas kedelai. Adapun mesin kedelai yang dihasilkan mempunyai tinggi sekitar 1000 $\mathrm{mm}$, panjang $900 \mathrm{~mm}$, lebar $500 \mathrm{~mm}$, kapasitas pengelupasan sekitar $150 \mathrm{~kg} / \mathrm{jam}$, putaran mesin pengelupas $710 \mathrm{rpm}$, daya motor bensin 5,5 PK dan putaran motor bensin sekitar $1400 \mathrm{rpm}$.

Supaya penggunaan mesin pengelupas kedelai nantinya dapat maksimal, maka tim pengabdi melakukan pelatihan pada pemilik usaha tempe "Jumari". Pelatihan yang dilakukan meliputi: cara mengopersionalkan mesin, pemeliharaan dan perbaikan mesin (lihat Gambar 4).

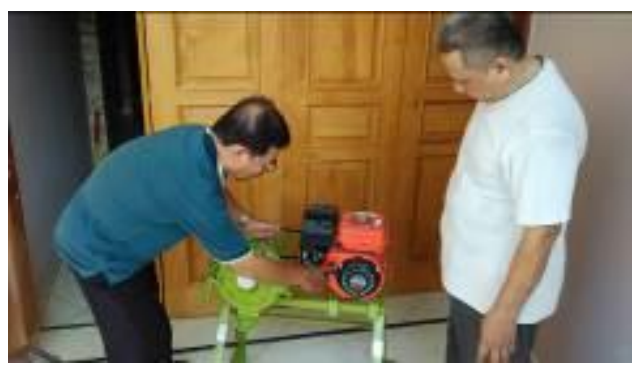

Gambar 4. Pelatihan penggunaan mesin pengelupas kedelai

Setelah penyerahan mesin, dilakukan pengujian efektivitas mesin pengelupas kedelai yang dihasilkan dari kegiatan pengabdian. Pengujian dilakukan dengan cara membandingkan banyaknya hasil kedelai yang terkelupas antara yang menggunakan mesin hasil pengabdian dan yang secara manual (biasa) juga hasil kualitas kebersihan tempe yang dihasilkan.

Hasil evaluasi dari uji efektivitas yang dilakukan dengan cara mengelupas kedelai yang diproduksi setelah adanya kegiatan pengabdian yaitu sebanyak $150 \mathrm{~kg}$ sebagai bahan pembuatan tempe yang dilakukan secara tradisional/manual dengan diinjak injak dan pengelupasan kedelai dengan menggunakan mesin hasil kegiatan pengabdian. Hasil efektivitas dilihat dari waktu yang digunakan untuk mengelupas kedelai $150 \mathrm{~kg}$ sebanyak tiga kali dapat dilihat pada Tabel 1.

Tabel 1. Waktu Pengelupasan Kedelai

\begin{tabular}{ccc}
\hline $\begin{array}{c}\text { Banyaknya } \\
\text { Kedelai } \\
\text { yang }\end{array}$ & $\begin{array}{c}\text { Secara } \\
\text { Tradisional/ } \\
\text { Manual (Menit) }\end{array}$ & $\begin{array}{c}\text { Menggunakan } \\
\text { Mesin (Menit) }\end{array}$ \\
\hline
\end{tabular}




\begin{tabular}{ccc}
\hline $\begin{array}{c}\text { Dikelupas } \\
(\mathbf{K g})\end{array}$ & & \\
\hline 150 & 123 & 62 \\
150 & 119 & 60 \\
150 & 121 & 58 \\
\hline Rata-rata & 121 & 60 \\
\hline
\end{tabular}

Berdasarkan hasil yang ada pada Tabel 1, jelaslah bahwa adanya kegiatan pengabdian yang telah dilakukan telah meningkatkan kapasitas produksi tempe usaha kecil "Jumari" yang semula sebelum kegiatan $125 \mathrm{~kg}$ (900 potong tempe) sekarang meningkat menjadi $150 \mathrm{~kg}$ (1050 potong tempe) berarti telah terjadi peningkatan produksi tempe sebanyak $25 \mathrm{~kg}$ (20\%) setiap hari. Untuk pengelupasan kedelai yang semula secara manual/tradisional dengan cara diinjak injak memerlukan waktu 121 menit, setelah menggunakan mesin pengelupas waktu yang dibutuhkan menjadi 60 menit, berarti pengelupasan kedelai menjadi lebih cepat sekitar 61 menit (50\%) dari pengelupasan sebelumnya yang secara manual. Peningkatan produksi tempe disertai dengan peningkatan pendapatan usaha kecil tempe yang semula sekitar Rp.350.000 sampai Rp.400.000 perhari sekarang pendapatan bersihnya menjadi Rp.405.000 sampai Rp.455.000 perhari.

Untuk mengetahui kualitas tempe dari hasil mesin kegiatan pengabdian dibandingkan dengan kualitas tempe yang pengelupasannya secara manual/tradisional dengan diinjak injak adalah dengan melihat hasil potongan tempe yang telah difermentasi selama dua hari. Hasil potongan tempe dengan menggunakan mesin pengelupas kedelai dan potongan tempe yang pengelupasannya secara manual/tradisional dengan cara diinjak injak adalah seperti terlihat pada Gambar 5 dan 6.

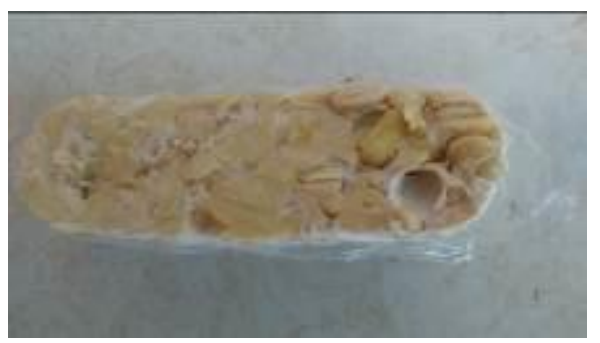

Gambar 5. Potongan tempe dari pengelupasan menggunakan mesin

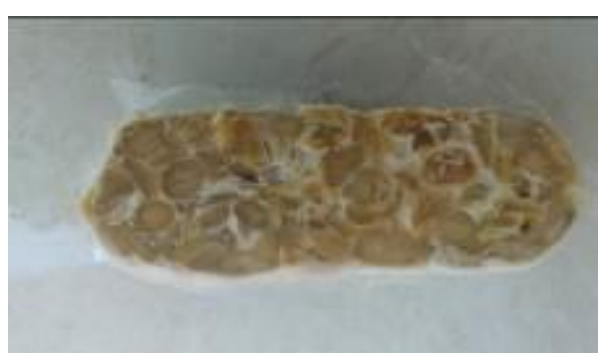

\section{Gambar 6. Potongan tempe dari pengelupasan secara tradisional}

Melihat Gambar 5 dan 6, bila dicermat dengan teliti nampak bahwa potongan tempe dengan menggunakan mesin lebih bersih dibandingkan dengan potongan tempe yang pengelupasannya dengan cara tradisional dinjak injak. Untuk potongan tempe yang pengelupasannya menggunakan mesin warnanya lebih cerah dari pada yang pengelupasan dilakukan secara tradisional.

\section{Pembahasan}

Pemberdayaan pada usaha kecil tempe "Jumari" telah menghasilkan mesin pengelupas kedelai. Mesin pengelupas kedelai yang dihasilkan tersebut dari hasil uji efektivitas telah mempercepat waktu pengelupasan kedelai. Tentunya hasil percepatan ini akan menjadikan waktu pengelupasan menjadi lebih cepat. Atas dasar demikian hasil kegiatan pemberdayaan yang telah dilakukan ini memperkuat penelitian yang telah dilakukan oleh Fauzi (2014: 7) bahwa penggunaan mesin sederhana untuk pengelupasan kulit kedelai berdampak pada penghematan waktu produksi tempe. Selain mengehemat waktu penggunaan mesin pengelupas kedelai juga menghemat tenaga (Santoso 2002: 15).

Setelah pengelupasannya menggunakan mesin hasil pemberdayaan dari pengabdian yang dilakukan tempe yang dihasilkan menjadi lebih bersih, sehingga hiegenis sebagai bahan makanan. Hasil ini sesuai dengan yang dikemukakan oleh Santoso (2007: 23) bahwa penggunaan mesin menjadikan pengelupasan dijamin lebih bersih dan kualitasnya terkontrol. Atas dasar demikian penggunaan mesin pengelupas yang dihasilkan dari kegiatan pengabdian akan membuat tempe yang dihasilkan dari usaha kecil tempe "Jumari" 
tidak berwarna gelap dan tidak ada batu batu kecilnya lagi.

Adanya peningkatan produksi yang semula $125 \mathrm{~kg}$ menjadi $150 \mathrm{~kg}$ setelah menggunakan mesin pengelupas hasil kegiatan pengabdian dimana semula tiap hari memproduksi tempe sebanyak 900 potong sekarang meningkat menjadi sekitar 1050 potong. Peningkatan produksi tempe setelah menggunakan mesin pengelupas kedelai hasil kegiatan pengabdian pada usaha kecil tempe "Jumari" adalah merupakan dampak dari efektivitas mesin yang dihasilkan dari kegiatan pemberdayaan yang sudah dilakukan. Hal ini diperkuat dari hasil penelitian Ariani, Mawardi dan Yoesoef (2017: 86) yang menjelaskan bahwa dengan menggunakan mesin pengelupas kedelai ada peningkatan produksi tiap tahunnya pada usaha pembuatan tempe cap Bunga Mawar di Gampong Uteun Bayi, Kecamatan Banda Sakti kota Lhokseumawe.

Peningkatan pendapatan bersih usaha tempe "Jumari" dari semula sekitar Rp.350.000 sampai Rp.400.000 sekarang pendapatan bersihnya menjadi Rp.405.000 sampai Rp.455.000 perhari berarti pendapatan bersihnya perhari meningkat sebesar Rp.50.000 (15\%) dari sebelumnya. Keuntungan usaha pembuatan tempe tersebut sudah lebih besar dari pada pembuatan tempe yang dilakukan di luar pulau Jawa di wilayah Kelurahan Binuang Kecamatan Binuang Kabupaten Tapin Provinsi Kalimantan Selatan, dimana untuk produksi $100 \mathrm{~kg}$ kedelai pendapatannya bervariasi ada yang Rp.89.470 dan ada juga yang Rp.157.840 (Hairun, Suslinawati dan Zuraida 2016: 50).

Sebenarnya besarnya keuntungan yang didapat usaha kecil tempe sangat bergantung dari banyak faktor yang mempengaruhinya. Untuk penjualan dengan tata niaga dengan sedikit pelaku yang terlibat maka keuntungan usaha pembuat tempe semakin besar, demikian pula sebaliknya penjualan dengan tata niaga banyak pelaku yang terlibat maka keuntungan yang diterima pembuat tempe semakin kecil (Aini, Purtomo S. dan Prianto 2016: 1). Untuk itu adanya penjualan langsung yang dilakukan usaha kecil tempe "Jumari" pada warung warung dan juga pada penjual tempe keliling, menjadikan tata niaganya lebih sedikit yang terlibat, sehingga keuntungannya menjadi lebih besar dibandingkan dengan usaha sejenis seperti yang telah dijelaskan.

Adanya peningkatan produksi, kualitas tempe yang bersih, dan juga peningkatan pendapatan, hal ini menunjukkan bahwa kegiatan pemberdayaan yang dilakukan telah berhasil menyelesaikan permasalahan yang dihadapi usaha kecil pembuatan tempe "Jumari". Namun demikian segala usaha masih perlu dilakukan terutama dalam pemberian permodalan, membantu pemasaran tempe agar dapat memasuki pasar swalayan dan mengganti peralatan yang ada dengan bahan stainless steel yang khusus untuk pengolahan makanan.

\section{SIMPULAN}

Berdasarkan uraian yang telah dijelaskan di atas, maka dapat disimpulkan sebagai berikut: pembuatan mesin pengelupas kedelai yang dihasilkan dari kegiatan pemberdayaan mempunyai tinggi $1000 \mathrm{~mm}$, panjang $900 \mathrm{~mm}$, lebar $500 \mathrm{~mm}$, kapasitas produksi pengelupasan sekitar $150 \mathrm{~kg} / \mathrm{jam}$, putaran mesin pengelupas $710 \mathrm{rpm}$, daya motor bensin 5,5 PK dan putaran motor bensin sekitar $1400 \mathrm{rpm}$, pengelupasan kedelai menggunakan mesin hasil pemberdayaan waktunya menjadil lebih cepat (sekitar 50\%) dari pada pengelupasan sebelumnya yang dilakukan secara tradisional/manual, hasil potongan tempe yang pengelupasan kedelainya menggunakan mesin hasil pemberdayaan lebih bersih dari pada potongan tempe yang pengelupasannya dilakukan secara tradisional/manual, penggunaan mesin pengelupas kedelai hasil pemberdayaan telah meningkatkan kapasitas produksi tempe sebesar $25 \mathrm{~kg}$ (sekitar 20\%) dari pada sebelumnya, terjadi peningkatan pendapatan sekitar Rp.50.000 (15\%) setelah menggunakan mesin pengelupas kedelai hasil pemberdayaan pada usaha kecil tempe "Jumari

\section{DAFTAR PUSTAKA}

Aini, QA, Purnomo, SR dan Prianto, FW.2016. Tata Niaga Industri Kecil Tempe di Kecamatan Genteng Kabupaten 
Banyuwangi. Artikel Ilmiah Mahasiswa, Jurusan Ilmu Ekonomi dan Studi Pembangunan, Fakultas Ekonomi, Universitas Jember (UNEJ).

Ariani, Lisa, Mawardi dan Yoesoef, Anwar 2017. Dinamika Usaha Tempe Cap Bunga Mawar di Gampong Uteun Bayi Kecamatan Banda Sakti Kota Lhokseumawe Banda Aceh 1995-2016. Jurnal Ilmiah Mahasiswa (JIM) Program Studi Pendidikan Sejarah, 2 (1): 76-89.

Fauzi, F. 2014. Perencanaan Alat Bantu Pengupas Kulit Kacang Kedelai Yang Sederhana untuk Meningkatkan Produktivitas Pengupasan Kulit Kacang Kedelai di PD Sari Asri. Jurnal Kalibrasi, 12(1).

Hairun, Suslinawati dan Zuraida, Ana 2016. Analisis Usaha Pembuatan Tempe (Studi Kasus pada Usaha Pembuatan Tempe “ Bapak Joko Sarwono") di Kelurahan Binuang Kecamatan Binuang Kabupaten Tapin. Al Ulum Sains dan Teknologi 2(1)

Nasirwan, Safril dan Adril, Elvis. 2007. Rancang Bangun Mesin Pengelupas dan Pemisah Kulit Kacang Kedelai Untuk Meningkatkan Kapasitas Secara Mekanis. Jurnal Teknik Mesin, 4 (1).

Santoso, H. B. 2002. Perontok Bijih Kedelai. Cetakan ke 8. Yogyakarta: Penerbit Kanisius.

2007. Susu dan Yoghurt Kedelai. Cetakan ke 14. Yogyakarta: Penerbit Kanisius.

Sayogo, Muharyono Hari dan Suwito, Djoko 2013. Perencanaan Mekanisme Mesin Pengupas Kulit Ari Kelapa. Jurnal JTM, 1 (2). 